\title{
On Bernal's Homage to Manila: A Review of Joel David's Manila by Night: A Queer Film Classic
}

Ronald Baytan

It is unfortunate that great works of art in the Philippines usually remain understudied. A critic can count with his/her fingers the single-authorship books on the works of Philippine National Artists like Manuel Conde, Ishmael Bernal, and Lino Brocka. That is why the publication of Joel David's Manila by Night: A Queer Film Classic, published by Arsenal Pulp Press (Vancouver, Canada) in 2017 is auspicious news. After all, Ishmael Bernal is undisputedly one of the country's finest directors-and Manila by Night, one of his most outstanding works.

Divided into five main sections (three chapters plus introduction and conclusion), Manila by Night: A Queer Film Classic provides an in-depth look at the relevant contexts of Bernal's film. It situates the work within the history of Philippine cinema, gives adequate biographical information about the auteur, discusses the tradition (both local and foreign) to which Manila by Night belongs, and raises key points about the film's aesthetics which has not been remarked upon by other critics. The book contains three special sections as well: a quick discussion of queer Filipino films; a list of multi-character movies; and an interview with the late Bernardo Bernardo.

While the detailed discussion of Philippine cinema and its contexts gives one the feeling that the audience is primarily Western, the information David provides his readers-Filipino or non-Filipino-is valuable. For it gives the readers a crash course on Philippine cinema and more importantly 
it enables them to read the film in its proper historical and cultural contexts, which are necessary to a deeper appreciation of the film.

The introduction-David's personal narrative about his affair with the movies and with Bernal's masterpiece-is quite laudable as it succinctly discusses salient points about the film and underscores its relationship with the Marcosian years and his dissatisfaction with the critics' appraisal of the film (e.g, one award-giving body gave Bernal the best director award but it denied the film the Best Picture plum). While Bernal's brand of realism did not sit squarely with the crop of social realist films produced by his contemporaries like Lino Brocka and Mike de leon, what became a critical "liability" for Manila by Night was that Bernal's aesthetics ran against the established and acceptable mode of filmmaking espoused by formalist (and social realist) critics then. Critics like Mario Bautista (2001/1980) and Isagani R. Cruz (1980), as pointed out in the book, mentioned the technical problems of Manila By Night in their reviews. This appraisal, following David's argument, spoke not so much of Bernal's or the film's limitations, as much as "the critics' unfamiliarity with documentary and Third-Cinema stylistics..." (David , 2017, p. 53). The tragedy of Bernal then was that he was way ahead of his time.

Bernal's appropriation of Altman's multi-character format, the misunderstood aesthetics of Bernal especially the visual and sonic features of Manila by Night, and briefly the gay and lesbian identities in the filmthese topics are already evident in David's earlier works. What David has done is to weave these ideas into a seamless book with a more pointedly queer focus.

In the essay "A Second Golden Age (An Informal History)" in The National Past Time, David (1990) mentions that "the highest artistic point of the Golden Age and, by reasonable extension, of Philippine cinema thus far, was attained with Bernal's Manila by Night" (p. 8) and briefly explains how Bernal, through his adoption of "the then-emergent character-based multi-narrative process" (p. 9), succeeds in showing "that a personalized and multi-stylized approach to this manner of presentation of subject matter was possible, and that the filmmaker could choose to oppose the expectation of a final and logical conclusion and still justify an open-endedness in terms of his material (pp. 9-10). In Fields of Vision, David (1995) mentions Manila by Night three times in the last four sections of the essay "The 'New' Cinema in Retrospect." In the sub-section "Sexual Libertarianism," he states: "The gay character assumed a more realistic, if not sympathetic, treatment during the Second Golden Age... assuming lead character capability, in all his flaming glory, in Manila by Night" (p. 27). In the special issue of Kritika Kultura on Manila by Night, David's article titled "Film Plastics of Manila by Night" 
aims to "re-evaluate the movie's aesthetic stature vis-à-vis movements specific to Third Cinema, focusing on ethnographic film making" (2012a, p. 37). Examining the "visual surface" and sound of Manila by Night, David demonstrates that the film-contrary to the pronouncements made by critics-involved a careful "aesthetic deliberation" by Bernal (p. 36).

David (2017) singles out two of Bernal's acclaimed works, Nunal sa Tubig (1976) and Aliw (1979), as the precursor of Manila by Night. He states: "When Bernal and Ejercito resumed their producer-director collaboration in 1979, Bernal had adopted a radically different style from any of his earlier films: he was now using hand-held cameras, improvised scenes, noise-filled soundtracks comprising pointedly observed inner-city chatter, snatches of industrial and pop music sounds, and (a holdover from his earlier work, including Nunal sa Tubig) indeterminate closures" (2017, p. 49). David further adds: "It was an opportunity for Bernal to apply his skills in documentary and complex narrative structuring which he'd successfully deployed in his last Seven Stars project, to a wide array of characters-all of whom inhabited the Philippine martial-law era's urban nightlife" (p. 52). On Aliw, he says, "With the triumph of Aliw as both a commercial attempt and a triple-character narrative, Bernal effectively ushered in an era of multicharacter film production in the Philippines..." (p. 130). Since both AIiw and Manila by Night are about "the urban underworld and deploy documentary film aesthetics," David contends that "Manila by Night may be regarded as the sequel-of sorts of Aliw" (p. 131).

While Philippine film criticism in the 1980s had started talking about gay and lesbian identities, the discourse (especially in the country) then was not yet ripe for the anti-homophobic and, to use the term loosely, queer politics of Bernal. The heart of the book is the queerness or queer elements in Manila by Night. Thus, it is expected that David analyzes the characters Manay Sharon and Kano and their relationships with other characters like Febrero, Alex, and Bea. David (2017) asserts, "The movie's moral interlocutor is its strong-willed, promiscuous gay male character Manay, but its moral center is arguably its unmitigatedly Othered character Kano..." (pp. 160-161). Queerness in the book, however, is not limited to an analysis of the characters or the transgressive politics of the film. David states: "The queerness in Manila by Night resides as much in its politicization of socalled perverse sexualities as it does in its reconfiguration of film form in order to critique conventional heroes" (pp. 144-145). David shows that "one could argue that, even more than the visual surface, the sound design of Manila by Night exemplified a queering of technique-a conflation of unruly source material with the exacting discipline of studio recording-in 
order to present a result that was faithful not to the demands of standard film practice, but to the nature of the original material itself" (p. 111).

An interesting presence in the book is Lino Brocka. In a way, one can say that Bernal has become the Other of Brocka. After all, the two are always compared or mentioned side by side each other in critical essays on Philippine cinema (see Lumbera, 2011a, for example). It is inevitable that a discussion of Brocka's Maynila: Sa Mga Kuko ng Liwanag should surface for, according to David (2017), Bernal had "awareness of Lino Brocka's much admired city film, Maynila" (p. 50). The comparison is apt since both canonical city films are about Manila, both are helmed by gay directors, and both have queer elements. In a way, David's gesture is a follow-up on "Manila, sa mga Kuko ng Liwanag and Manila by Night: The City According to Brocka" by Clodualdo del Mundo, Jr. (2001/1987), which the author concludes with the lines, "Bernal surrenders to a seemingly uncontrollable world and celebrates the city as a way of life; Brocka is ridden with anguish and struggles against the condition of exploitation" (p. 93). While Del Mundo's take is thematic, David's zeroes in on the queer politics of the two films.

Given the technical polish of Maynila (cinematography by Mike de leon no less), David (2017) admits, "...Maynila had (and continues to have) the edge, with wider international acclaim” (p. 60). From queer lens, however, David demonstrates that Maynila is way behind Manila by Night. While Maynila is a much-lauded film, gayness - the innovation added by Brocka to the classic novel written by Edgardo M. Reyes-is also the source of its limitations. David offers a very informative discussion of the gay sequence involving Julio's foray into commercial (male-to-male) sex work. A critic may say that Brocka's queering of the novel is laudable, fits his vision for the lead character, and offers telling shots on the dehumanizing aspect of sex work (especially with the Bullet scene). However, David avers: "An overlooked paradox is the fact that the extended gay-hustler sequences (still perceivable from the shorter scenes that remain) are both unconsciously homoerotic yet indubitably anti-queer..." (p. 66). Aside from queer politics, Brocka's film, David stresses, has other problems:

Even discounting its homophobia, Maynila also suffered from a surfeit of identity troubles, even by still-contemporary politically correct standards: its protagonists were fairskinned mestizo types, its villain a small-time Chinatown proprietor ... and the sidewalk gang that fatally lynches its male protagonists comprise lumpenproles. Some of these types appeared in Manila by Night, to be sure, but the 
latter's satirical approach and deconstruction of the social evil served to overturn the melodramatic earnestness of the Brocka text. (p. 68)

It must be emphasized though that Brocka was working on a material not his own, and this partly limited his choices as a gay filmmaker. Nevertheless, David's criticism holds water.

Despite David's critique of Brocka's queer politics, David has nonetheless acknowledged the importance of Brocka in Philippine queer cinema by referencing the landmark films Tubog sa Ginto [Dipped in Gold] (1970) and Ang Tatay Kong Nanay [My Mother the Father] (1978). While David (2017) critiques the latter film by saying it "ends with an unnecessarily sentimental plea for understanding" (p.71), David asserts that it certainly has "better identity politics" than Tubog sa Ginto (p. 71). Brocka's Macho Dancer (1988) - which has spawned a series of films showcasing exotic Asian male bodies for the Western gay audience-is also problematic as, according to David (2017), it "takes a disapprovingly voyeuristic approach to the excesses of gay nightlife..." (p. 71).

David's queer reading in the book is adequate and laudable. One little suggestion though: Given that the audience is primarily Western and the film Manila by Night comes from the non-Western world, David could have unpacked-albeit briefly-the local sex/gender terms (e.g., lalake vs bakla, tomboy vs. babae) (see Garcia, 2008, for instance), and then related them to "queer" to provide the readers, especially non-Filipino readers, a little more grounding on the sexual identities in the country and on the specificity of their transgressive "queer" performances. David notes in his list of queer films how "queer, though a useful category," is "nearly impossible to execute in neat packages since it arguably abhors neatness to begin with" (p. 70). Precisely. While theorizing identity is certainly not the aim of the book, identity categories are so culture-specific that even a little discussion to mediate those from the West with the local ones would benefit the intended readers, especially since part of getting acquainted further with an unfamiliar or foreign film is knowing the specific sex culture from which the film in question springs.

The book's closing chapter begins with irony, a fitting trope for a filmmaker whose work is highly intelligent and ironic. Had the book been longer, it would have been wonderful to see a little foray into irony and religion, for this certainly figures in the film with its heavy use of religious images (e.g., The Last Supper in Virgie's house; the picture of Jesus Christ on the wall shot between Febrero and Manay Sharon whispering "I-loveyou's"). 
Reading David's work, one gets the feeling that despite David's claims that " $t$ ] he scholarly coverage of Manila by Night has made it the most academically productive Philippine film release in history" (2017, p. 159) and despite the fact that David's work addresses the scholarly oversight on salient aspects and techniques of the film, so much wonderful work can still be done on Maynila by Night and on Bernal. This is how David's work, given its earnestness and insights, inspires. Reading after reading, to borrow David's words, "we can be assured that it [Manila by Night] (and the culture of resistance that spawned it) can still be useful for any number of critical, formal, and social insights" (p. 161).

David's book gives the readers, especially Bernal fans, the heartwarming feeling that something has been done right, similar to the feeling one must have felt after reading Bienvenido Lumbera's review of Nunal sa Tubig in 1978 (reprinted in 2011b), Mario Hernando's illuminating essay on Bernal's first ten years as a director in 1981, Eulalio R. Guieb III's article on Nunal sa Tubig in 2000, Justino Dormiendo's biographical essay-cum-tribute to Bernal in 2003, and Patrick Campos's work on Manila by Night in 2012.

Informative, theoretically non-daunting, and lucid, David's homage to Bernal's Manila by Night is certainly a gem of a little book. After all, a masterpiece like Ishmael Bernal's Manila by Night deserves nothing less. 


\section{References}

Bautista, M. E. (2001). They said it couldn't be done. [Review of the film Manila by Night by I. Bernal]. In N. Tiongson (Ed.), Urian 1980-1989 (pp. 153-156). (Reprinted from Parade September 28, 1980).

Campos, P. (2012). Manila by Night as thirdspace. Kritika Kultura, (19), 139-165. Retrieved from http:// kritikakultura.ateneo.net/type/issue/no-19.

Cruz, I. R. (1980, October 5-11). Review: Manila by Night. TV Times, 45.

David, J. (1990). The national pastime: Contemporary Philippine cinema. Pasig, Philippines: Anvil Publishing, Inc.

David, J. (1995). Fields of vision: Critical applications in recent Philippine cinema. Quezon City, Philippines: Ateneo de Manila University Press.

David, J. (2012a). Film plastics in Manila by Night. Kritika Kultura, (19), 36-69. Retrieved from http:// kritikakultura.ateneo.net/type/issue/no-19'

David, J. (2012b). Forum Kritika: A closer Look at Manila by Night: An introduction. Kritika Kultura, (19), 6-13. Retrieved from http://kritikakultura.ateneo.net/type/issue/no-19

David, J. (2017). Manila by Night: A queer film classic. Vancover, Canada: Arsenal Pulp Press.

Del Mundo, C., Jr. (2001). Maynila, sa mga Kuko ng Liwanag and Manila by Night: The city according to Brocka and Bernal. In N. Tiongson (Ed.), Urian 1980-1989 (pp. 88-93). (Paper first read at the 1987 Hawaii International Film Festival Conference on "The City and Film" and reprinted from Philippine Daily Inquirer 1 January 1996).

Dormiendo, J. (2003). The finest poet of Philippine cinema. In H. Beltran Jr. (Ed.), The national artists of the Philippines 1999-2003 (pp. 29-34). Pasay, Philippines: Cultural Center of the Philippines; Pasig, Philippines: Anvil Publishing, Inc.

Garcia, J. N. C. (2008). Philippine gay culture: Binabae to bakla, silahis to MSM ( $2^{\text {nd }}$ ed). Quezon City, Philippines: The University of the Philippines Press.

Guieb, E.R. III. (2000). Historico-geographical Imaginations in Ishmael Bernal's Nunal sa Tubig. In R. Tolentino (Ed.), Geopolitics of the visible: Essays on Philippine film cultures (pp. 125-141). Quezon City, Philippines: Ateneo de Manila University Press.

Hernando, M.A. (2001). Ishmael Bernal: Merging art and commercialism. In N. Tiongson (Ed.), Urian 19801989 (pp. 276-287). (Reprinted from Far East Banknotes 1981).

Lumbera, B. (2011a). Brocka, Bernal \& co.: The arrival of new cinema. In B. Lumbera, Re-viewing Filipino cinema (pp. 124-135). Mandaluyong, Philippines: Anvil Publishing. (Reprinted from Philippine Daily Express August 7, 1978).

Lumbera, B. (2011b). Nunal sa Tubig Revisited. In B. Lumbera, Re-viewing Filipino cinema (pp. 108-110). Mandaluyong, Philippines: Anvil Publishing. (Reprinted from Philippine Daily Express August 7, 1978).

Tiongson, N. G. (Ed.) (2001). The Urian anthology, 1980-1989: Film essays and reviews by the Manunuring Pelikulang Pilipino with a filmography of Philippine movies, 1980-1989. Manila, Philippines: Antonio P. Tuviera. 


\section{Filmography}

Blas, E.S. (Producer) \& Brocka, L. (Director) (1970) Tubog sa Ginto (Dipped in Gold). [Motion Picture]. Philippines: Lea Productions.

De Guia, B.C. (Producer) \& Brocka, L. (Director) (1988) Macho Dancer. [Motion Picture]. Philippines: Award Films, Special People Productions, and Viva Films.

De Leon, M., \& Manotok, S., Jr. (Producers) \& Brocka, L. (Director) (1975). Maynila: Sa mga Kuko ng Liwanag (Manila: In the Claws of Light). [Motion Picture]. Philippines: Cinema Artists.

Ejercito, E., \& Ejercito, J. (Producers), \& Bernal, I. (Director) (1976) Nunal sa Tubig (A Speck in the Water). [Motion Picture]. Philippines: Crown Seven Film Productions.

Ejercito, M., Ejercito, J.M., \& Santos, J. L. (Producers) \& Bernal, I. (Director). (1979). Aliw (Pleasure) [Motion Picture]. Philippines: Seven Stars Productions.

Monteverde, L. Y. (Producer) \& Bernal, I. (Director) (1980) Manila by Night (City After Dark) [Motion Picture]. Philippines: Regal Films.

Yu, J.B. (Producer) \& Brocka, L. (Director) (1978). Ang Tatay Kong Nanay (My Father the Mother). [Motion Picture]. Philippines: Lotus Films, Inc.

RONALD BAYTAN is an associate professor of literature and creative writing at De La Salle University. He holds a Ph.D. in English Studies from the University of the Philippines, Diliman. (Correspponding author: ronald.baytan@dlsu.edu.ph) 